\title{
O nabyciu nieruchomości rolnej przez osobę bliską zbywcy. Uwagi na kanwie uchwały Sądu Najwyższego z dnia 22 czerwca 2017 r., III CZP 24/17
}

Problemy interpretacyjne, które sprawia regulacja znowelizowanej ustawy o kształtowaniu ustroju rolnego ${ }^{1}$ (dalej: u.k.u.r.) urastają do rangi niemal anegdotycznej; są przedmiotem coraz większej liczby wypowiedzi w piśmiennictwie. Nie inaczej jest w orzecznictwie Sądu Najwyższego, który dnia 22 czerwca 2017 r. podjął uchwałę w kwestii dotyczącej interpretacji art. 2b u.k.u.r. ${ }^{2} \mathrm{~W}$ uchwale tej poruszono zagadnienie dopuszczalności przeniesienia własności na rzecz osoby bliskiej zbywcy nieruchomości rolnej przez osobę (zbywcę), której dotyczy zakaz zbywania tej nieruchomości wynikający z art. 2 b ust. 2 u.k.u.r. Sąd Najwyższy uznał, że w świetle u.k.u.r. jest to dopuszczalne, a zbywca nie musi uzyskiwać zgody sądu na zbycie tej nieruchomości, o której to zgodzie mowa w art. $2 \mathrm{~b}$ ust. 3 u.k.u.r.

Prima facie mogłoby się wydawać, że rozstrzygnięcie to stanowi rozsądną odpowiedź na jeden z problemów powstałych na gruncie wielce niedoskonałego uregulowania pozycji nabywcy nieruchomości rolnej zawartego w art. 2b u.k.u.r. Jednak analiza argumentów przedstawionych przez Sąd Najwyższy na poparcie zajętego w uchwale z dnia 22 czerwca 2017 r. stanowiska stawia pod znakiem zapytania jego trafność.

Sąd Najwyższy stwierdza, że samo brzmienie ustawy nie wskazuje na to, że właściciel nieruchomości będący osobą bliską potencjalnego nabywcy nie może zbyć tej nieruchomości na jego rzecz, jeśli na zbywcy ciąży obowiązek o którym mowa $w$ art. $2 b$ ust. 2 u.k.u.r. Taki wniosek, zdaniem Sądu Najwyższego, można z kolei wysnuć dopiero z zestawienia przepisów ust. 4 oraz 1 i 2 art. 2b u.k.u.r. (ściśle rzecz ujmując - Sąd Najwyższy stwierdza, że zestawienie to może sugerować taki wniosek). W uzasadnieniu wyroku stwierdza się, rozwijając przedstawione powyżej rozważania: Niewątpliwie bowiem nabywca po dniu 30 kwietnia 2016 $r$. nieruchomości rolnej od osoby bliskiej nie podlega rygorom określonym $w$ art.

1 Ustawa z dnia 11 kwietnia 2003 r. o kształtowaniu ustroju rolnego, Dz.U. z 2016 r. poz. 2052.

2 Uchwała Sądu Najwyższego z dnia 22 czerwca 2017 r., sygn. akt III CZP 24/17. 
2 b ust. 1 i 2 u.k.u.r. Można by więc - a contrario - wnosić, że nabywca po dniu 30 kwietnia 2016 r. nieruchomości rolnej od osoby obcej podlega wskazanym rygorom.

Wydaje się, że przez „brzmienie” przepisu Sąd Najwyższy rozumie konkretne postanowienie przepisu prawa określające wprost oznaczone konsekwencje prawne. Można by więc powiedzieć, że przy takim ujęciu, z brzmienia przepisu wynikałby zakaz zbywania nieruchomości rolnej osobie innej niż osoba bliska, gdyby przepis taki zawierał konkretny zwrot mówiący wprost, że osoby, na których ciąży obowiązek prowadzenia gospodarstwa rolnego oraz zakaz zbywania nabytej wcześniej nieruchomości rolnej, nie mogą ich zbyć również na rzecz osób bliskich. Takiego przepisu, de lege lata, u.k.u.r. nie zawiera. Stanowisko o niedopuszczalności dokonania takiej czynności prawnej bez zgody sądu, o której mowa w ust. 3 art. 2b u.k.u.r., uzasadnione może być przez zaprezentowane w uzasadnieniu uchwały Sądu Najwyższego, a przywołane powyżej, zabiegi interpretacyjne o pewnym stopniu złożoności, mające za przedmiot w sumie trzy przepisy prawa (ust. 1, 2 i 4 art. 2b u.k.u.r.).

Trzeba mieć na uwadze, że z poszczególnych przepisów zawartych w art. $2 \mathrm{~b}$ u.k.u.r. dekoduje się przede wszystkim normy prawne statuujące obowiązek prowadzenia działalności rolniczej w gospodarstwie ${ }^{3}$, w skład którego wchodzi nabywana nieruchomość, a także wynika stamtąd zakaz zbywania nieruchomości i oddawania jej w posiadanie przez jej nabywcę. Źródłem tych unormowań są ust. 1 i 2 art. $2 \mathrm{~b}$ u.k.u.r. Rola przepisu ust. 4 art. $2 \mathrm{~b}$ u.k.u.r. (odnośnie dopuszczalności zbycia nieruchomości w okresie 10 lat od jej nabycia) polega na tym, że jego postanowienia służą dookreśleniu (skorygowaniu) wywodzonej z ust. 2 art. 2b u.k.u.r. modyfikacji zakresu zastosowania normy kompetencyjnej, z której wynika kompetencja do rozporządzania nieruchomością przez jej właściciela (nabywcę).

Adresaci obowiązków wskazanych w ust. 1 i 2 art. 2b u.k.u.r. określeni są jako „nabywcy nieruchomości”, co oznacza, że - w kontekście definicji zwrotu „nabycie nieruchomości rolnej" zawartej w art. 2 pkt 7 u.k.u.r. - krąg tych adresatów wyj-

Precyzyjnie co do wynikającego z art. 2b ust. 1 u.k.u.r. obowiązku prowadzenia gospodarstwa należałoby raczej widzieć dwie normy prawne - w pierwszej adresatem są podmioty niebędące osobami fizycznymi które obciąża obowiązek prowadzenia gospodarstwa i drugą normę, której adresatem są osoby fizyczne, a z której wynika obowiązek prowadzenia osobiście gospodarstwa rolnego. O sposobie rozumienia zwrotu „prowadzenie gospodarstwa rolnego" zob. J. Bieluk, Ustawa o kształtowaniu ustroju rolnego. Komentarz, Warszawa 2016, s. 112.

W zakresie, w jakim art. $2 b$ ust. 2 u.k.u.r. dotyczy zakazu zbywania nieruchomości - mamy w istocie do czynienia z przepisem dookreślającym zakres zastosowania normy kompetencyjnej, z której wynika kompetencja do rozporządzania nieruchomością rolną przez jej właściciela, na którym ciążą obowiązki z art. 2b u.k.u.r. (art. 140 kc.); zob. odnośnie kompetencji rozporządzania rzeczą uwagi P. Machnikowskiego, (w:) System prawa prywatnego. Tom III. Prawo rzeczowe, E. Gniewek (red.), Warszawa 2013, s. 13. W odniesieniu do tej regulacji w niniejszym artykule mówi się również o „zakazie zbywania nieruchomości”. Przepis art. 2 b ust. 2 u.k.u.r. w zakresie, w jakim stanowi o zakazie oddawania nieruchomości w posiadanie jest również ograniczeniem kompetencji właściciela do rozporządzania nieruchomością (np. przez ustanowienie prawa użytkowania), ale też jest ograniczeniem zasady swobody umów (art. $353^{1}$ kc.) w odniesieniu do czynności prawnych zobowiązaniowych (np. dzierżawa, najem). 
ściowo ${ }^{5}$ został określony maksymalnie szeroko. Krąg adresatów zakazu zbycia nieruchomości jest dookreślony (zmodyfikowany) przez art. 2b ust. 4 u.k.u.r., który wyłącza z ich zakresu wskazanych w art. 2a ust. 3 pkt 1, 2 i 3 u.k.u.r. nabywców nieruchomości. Tym samym adresatami powinności wynikających z ust. 1 i zakazów z ust. 2 art. 2b u.k.u.r. są podmioty, które stały się właścicielami nieruchomości wskutek zdarzeń określanych jako „nabycie nieruchomości”, z wyłączeniem sytuacji, gdy nabycie następuje w warunkach wynikających z art. 2a ust. 3 pkt 1, 2 i 3 u.k.u.r. Stąd osoba inna niż osoba bliska zbywcy i jednocześnie niepodpadająca pod zakres któregoś z pozostałych wyłączeń, wskazanych w art. 2a ust. 3 pkt 1, 2 i 3, jest podmiotem, na którym ciąży obowiązek z art. 2 b ust. 1 bądź 2 . W świetle tych ustaleń nie budzi wątpliwości, że nabywca nieruchomości rolnej niebędący osobą bliską zbywcy (oraz gdy nie zachodzi żaden z pozostałych wyjątków przewidzianych w art. 2 b ust. 4 u.k.u.r.) nie może zbyć nabytej nieruchomości w terminie 10 lat od dnia jej nabycia.

Innym problemem jest precyzyjne określenie okoliczności, w których wyłączona jest kompetencja właściciela nieruchomości rolnej do jej zbycia. Innymi słowy po ustaleniu, że dany podmiot należy do osób, wobec których aktualny jest 10-letni zakaz zbycia nieruchomości, określić jeszcze trzeba, w jakich okolicznościach wiążący jest ten zakaz. Czy dotyczy on każdego ewentualnego przypadku zbycia nieruchomości, czy też istnieją stany faktyczne, w których zakaz ten nie jest aktualny i czy taką okolicznością jest zbycie nieruchomości na rzecz osoby bliskiej zbywcy, którego to zbywcy dotyczy zakaz z art. 2 b ust. 2 u.k.u.r.? Otóż zakaz ten - zgodnie z literalnie odczytaną treścią przepisów u.k.u.r. - może być uchylony jedynie w razie wyrażenia zgody na zbycie nieruchomości przez sąd (vide art. 2b ust. 3 u.k.u.r.). Zgoda sądu dotyczyć ma jednak konkretnego stanu faktycznego. Natomiast w treści u.k.u.r. brak jest jakiejkolwiek regulacji określającej w sposób generalny bądź abstrakcyjny ewentualnych nabywców czy szczególne okoliczności, których by nie dotyczył zakaz zbywania nieruchomości z art. 2b ust. 2 u.k.u.r. obciążający potencjalnego zbywcę, w tym dotyczący zbycia dokonywanego przez niego na rzecz osoby bliskiej.

Jak widać, dochodząc do wniosków zaprezentowanych powyżej na tle art. 2b ust. 1, 2 i 4 u.k.u.r., mamy w istocie do czynienia z operacją mieszczącą się w granicach interpretacji językowej tych przepisów. Jak najbardziej uzasadnione jest więc stanowisko, że wykładnia językowa prowadzi do konkluzji, iż właściciel nieruchomości, na którym spoczywają obowiązki wskazane w art. 2b u.k.u.r., nie może zbyć nieruchomości w 10-letnim okresie przypadającym po jej nabyciu na rzecz osoby bliskiej. Niczego w tej konstatacji nie zmienia to, że wniosek ów nie wynika 
z „brzmienia” ustawy, a więc że nie ma przepisu wprost zawierającego zwrot mówiący o zakazie zbycia nieruchomości na rzecz osoby bliskiej przez właściciela, na którym ciążą obowiązki określone w art. 2b u.k.u.r. Wykładnia językowa nie ogranicza się wszak jedynie do prostej egzegezy zwrotów wprost określających skutki prawne pewnych zdarzeń. Trzeba ją widzieć w szerszym kontekście „pozyskania" normy prawnej z wielu przepisów prawa, w tym (tak jak w przypadku art. $2 b$ ust. 4 u.k.u.r.) zawierających odesłania do innych przepisów. Przy tym - art. $2 b$ ust. $4 \mathrm{w}$ zw. $z$ art. 2 a ust. 3 pkt 1 u.k.u.r. należy uznać za jednoznaczne językowo i w związku z tym za pozwalające określić na podstawie samych językowych zabiegów interpretacyjnych zakres okoliczności, w których wyłączone jest powstanie dla nabywcy nieruchomości obowiązków, o których mowa w art. 2b u.k.u.r., a także - odnośnie osób, co do których ustalimy, że obowiązki te powstają - okoliczności, w których obowiązki te są aktualne.

Sąd Najwyższy nie wyjaśnia, co jest uzasadnieniem dla zawartego w treści uchwały stwierdzenia, zgodnie z którym „zacieśnieniem” (tak w treści uchwały przyp. R.M.) wyjątku jest rozumienie art. 2 b ust. 4 u.k.u.r. w ten sposób, że zawarty tam wyjątek dotyczący osób bliskich odnosi się tylko do przypadków, gdy pierwszy nabywca nieruchomości rolnej po wejściu w życie tego przepisu był osobą bliską zbywcy (a już nie do przypadków, gdy nabycie nieruchomości nastąpiło od osoby obcej). Mówiąc o wykładni „zacieśniającej”, rozumie się zazwyczaj, że rezultatem przeprowadzonej wykładni jest węższy sposób rozumienia zakresu zastosowania albo normowania normy prawnej niż wynikający z zastosowania reguł wykładni językowej ${ }^{6}$. W tym przypadku trudno byłoby przyjąć taki sposób rozumienia słowa „zacieśnienie”. Jest tak, ponieważ w treści uchwały Sąd Najwyższy nie wskazuje, jak na gruncie reguł wykładni językowej osiągnąć inny niż ten, niezacieśniający rezultat zabiegów interpretacyjnych mających za przedmiot art. $2 b$ ust. 4 u.k.u.r. Jednak kontekst użycia tego terminu w treści uchwały może wywołać wrażenie, że odrzucony przez Sąd Najwyższy sposób rozumienia wyjątku z art. 2b ust. 4 u.k.u.r. - na gruncie już tylko reguł wykładni językowej - jest nadmiernie restryktywny i że istnieje jakiś sposób jego rozumienia niezacieśniający, który nie stoi w sprzeczności z brzmieniem ustawy. Jednak w uzasadnieniu uchwały brakuje jakichkolwiek rozważań w tym zakresie. W szczególności nie wskazano, które wyrażenia zawarte w ust. 2, 3 i 4 art. 2b u.k.u.r. traktowane są jako źródło wątpliwości co do ich znaczenia uzasadniających przekonanie, że istnieją różne ich sposoby rozumienia rzutujące na ustalenie zakresu zakazu zbycia nieruchomości w okresie 10 lat od jej nabycia.

Niezależnie od argumentacji zawartej w uchwale Sądu Najwyższego w literaturze wyrażono pogląd, zgodnie z którym z pierwszej części art. 2b ust. 4 u.k.u.r. mó- 
wiącej o podmiotach, o których mowa w art. 2a ust. 3 pkt 1 wynika, po pierwsze, że dla nabywcy nieruchomości, o którym mowa w art. 2a ust. 3 pkt 1 u.k.u.r., nie powstają obowiązki wynikające $\mathrm{z}$ art. $2 \mathrm{~b}$ u.k.u.r. oraz, po drugie, że osoba będąca właścicielem nieruchomości rolnej, na której ciążą obowiązki wynikające z art. 2b u.k.u.r., może zbyć nieruchomość rolną na rzecz osoby wskazanej w art. 2a ust. 3 pkt 1 nie narażając się na sankcję nieważności czynności prawnej o której mowa w art. 9 ust. 1 pkt 2 u.k.u.r. Z kolei w odniesieniu do podmiotów, o których mowa w drugiej części przepisu art. 2b ust. 4 u.k.u.r., określonych jako „nabywcy nieruchomości rolnej w przypadkach, o których mowa w art. 2a ust. 3 pkt 2 i 3", stwierdza się, że jeśli takie osoby nabędą nieruchomość rolną ${ }^{7}$, to nie powstają dla nich obowiązki $\mathrm{z}$ art. 2 b ust. 1 i 2, ale też właściciel nieruchomości, na którym ciążą obowiązki określone w art. 2b, nie może jej zbyć w okresie, w którym ciążą na nim te obowiązki na rzecz którejkolwiek kategorii osób wskazanych w art. 2a ust. 3 pkt 2 i 3 u.k.u.r. ${ }^{8}$

Pogląd ten nie jest zasadny. Terminologia, którą posłużył się prawodawca w art. 2b ust. 4 u.k.u.r., a więc zróżnicowanie w użyciu określenia ,podmiot” - w stosunku do przypadków określonych w art. 2a ust. 3 pkt 1 i ,nabywca” - dla przypadków z art. 2 a ust. 3 pkt 2 i 3, nie ma żadnego znaczenia, poza wskazaniem wyjątków od generalnej zasady powstania obowiązków związanych z jednym, konkretnym zdarzeniem którym jest nabycie własności nieruchomości rolnej (o czym mowa w art. 2b ust. 1 i 2 u.k.u.r.). Należy zwrócić uwagę na to, że art. 2 b ust. 3 pkt 1 w lit. a-d wskazuje na podmioty określone rodzajowo (osoby bliskie zbywcy ${ }^{9}$, jednostki samorządu terytorialnego, ,kościelne” osoby prawne, parki narodowe) lub indywidualnie (Skarb Państwa albo działający na jego rzecz Krajowy Ośrodek Wsparcia Rolnictwa). Sposób nabycia przez te podmioty (czynność prawna, akt administracyjny, skutek występujący ex lege) nie ma znaczenia - liczy się jedynie to, że nabycie nastąpiło przez ten właśnie podmiot. Terminologia ta jest pochodną charakteru wyjątków wskazanych w art. 2a ust. 3 pkt 1, 2 i 3 w zw. z art. 2b ust. 4 u.k.u.r. Otóż w pkt 1 ust. 3 art. 2 a u.k.u.r. wskazane są podmioty (osoby fizyczne bądź prawne), stąd $\mathrm{w}$ art. $2 \mathrm{~b}$ ust. 4 in principio mówi się o podmiotach wskazanych w owym przepisie. Z kolei w pkt 2 i 3 ust. 3 art. 2a u.k.u.r. wskazuje się jedynie zdarzenia skutkujące nabyciem własności nieruchomości (nabycie własności w wyniku dziedziczenia albo zapisu windykacyjnego, nabycie na podstawie art. $151 \mathrm{kc}$. albo $231 \mathrm{kc}$.) a nie podmiot, który nieruchomość nabywa. Tu określenie podmiotu jest pochodną zdarzenia powodującego zmianę stosunków własnościowych - istotny jest rodzaj zdarzenia prawnego, nie jest istotny status podmiotu będącego nabywcą wsku-

7 O ile oczywiście nabycie następuje od podmiotu, którego kompetencja do jej zbycia nie jest ograniczona przez art. $2 b$ ust. 2 u.k.u.r.

8 Tak, jak się wydaje, A. Michnik, Obowiązki nabywcy nieruchomości rolnej wynikające z ustawy z dnia 11 kwietnia 2003 r., „Krakowski Przegląd Notarialny” 2017, z. 1, s. 109 i nast.

9 Kategoria osoby bliskiej jest swoistą kategorią rodzajową, relatywną - pośrednio wskazuje na podmiot prawa cywilnego będący osobą fizyczną pozostającą względem zbywcy w relacji wynikającej z art. 2 pkt 6 u.k.u.r. 
tek zaistnienia tego zdarzenia. To właśnie tłumaczy posłużenie się w drugiej części art. 2 b ust. 4 u.k.u.r. zwrotem „nabywcy nieruchomości rolnej w przypadkach, o których mowa w art. 2 a ust. 3 pkt 2 i 3". Konkludując, zróżnicowanie terminologiczne w art. 2 b ust. 4 u.k.u.r. przejawiające się w użyciu terminów „podmiot” i „,nabywca", nie niesie z sobą żadnych skutków w procesie wykładni art. 2a ust. 1, 2 i 4 u.k.u.r., które by miały oparcie w tym zróżnicowaniu terminologicznym - jest ono neutralne dla określenia możliwości i skutków zbycia nieruchomości na rzecz osoby bliskiej przez podmiot, na którym ciążą obowiązki wynikające $\mathrm{z}$ art. $2 \mathrm{~b}$ u.k.u.r.

Sąd Najwyższy wskazuje, że na problem rozstrzygany w uchwale trzeba spojrzeć z szerszej perspektywy. Zaprezentował stanowisko, zgodnie z którym ustawodawca skonstruował rozwiązania prawne zawarte w u.k.u.r. w taki sposób, aby dać wyraz ogólnej idei „uwolnienia obrotu prawnego wewnątrz wspólnoty rodzinnej”. Ponadto według argumentacji Sądu Najwyższego, przyjęcie że osoba, która jest właścicielem nieruchomości rolnej i ciążą na niej obowiązki z art. $2 b$ u.k.u.r. nie może zbyć ich przed upływem wynikającego z tego przepisu 10-letniego okresu na rzecz osoby bliskiej, pozostawałoby w sprzeczności z założeniem u.k.u.r., którym jest zgodnie z jej preambułą - ,wzmocnienie ochrony i rozwoju gospodarstw rodzinnych, które w myśl Konstytucji Rzeczypospolitej Polskiej stanowią podstawę ustroju rolnego Rzeczypospolitej Polskiej”. Wprost zresztą Sąd Najwyższy stwierdza, że art. 2b ust. 4 u.k.u.r. wiąże się z celem u.k.u.r., którym jest ochrona i rozwój gospodarstw rodzinnych (art. 23 Konstytucji).

W pierwszej kolejności należy przyjrzeć się tezie o realizacji przez ustawodawcę ogólnej zasady preferencyjnego podejścia do obrotu wewnątrzrodzinnego w treści u.k.u.r. Ustawa - względem osób bliskich - zawiera rzeczywiście szereg regulacji wyłączających rygor poszczególnych rozwiązań w razie nabywania nieruchomości przez tę kategorię podmiotów. I tak, co skrupulatnie odnotowane zostało w treści uzasadnienia uchwały - osoba bliska zbywcy nie potrzebuje pozwolenia Dyrektora Generalnego KOWR na nabycie nieruchomości (art. 2a ust. 3 pkt 1 lit. a u.k.u.r.). Ponadto prawo pierwokupu nieruchomości rolnej dzierżawcy, jak i KOWR wyłączone jest w razie, gdy nabywcą nieruchomości jest osoba bliska zbywcy (art. 3 ust. 5 pkt 1 lit. a u.k.u.r.), wyłączone jest prawo nabycia KOWR w razie nabycia własności nieruchomości rolnej przez osobę bliską zbywcy (art. 4 ust. 4 pkt 2 lit a u.k.u.r.), prawo pierwokupu udziałów i akcji KOWR w razie ich zbycia osobie bliskiej (art. 3a ust. 2 pkt 1 u.k.u.r.), prawo nabycia KOWR w razie zmiany wspólnika bądź przystąpienia nowego wspólnika do spółki osobowej, gdy zamiast dotychczasowego wspólnika zostaje nim osoba jemu bliska albo nowym wspólnikiem zostaje osoba bliska któregokolwiek ze wspólników (art. 3b ust. 6 u.k.u.r.).

Sąd Najwyższy mając na uwadze przedstawione regulacje szczegółowe, niejako indukcyjne dochodzi do wniosku, że są one przejawem ogólnej realizowanej przez 
ustawodawcę zasady. Trzeba zaznaczyć, że takie wnioskowanie uogólniające walor rozwiązań szczegółowych w danym akcie prawnym nie jest niczym niezwykłym i generalnie jest aprobowane. Jednak na gruncie u.k.u.r. zaaplikowanie takiej argumentacji jest zawodne.

Po pierwsze, przeciwko zaakceptowaniu wniosku o generalnym charakterze preferencji osób bliskich na tle przepisów u.k.u.r. stoi na przeszkodzie zastosowana przez prawodawcę technika wprowadzania wyłączeń od ograniczeń w obrocie przewidzianych w tym akcie prawnym. Prawodawca, w przypadku kwestii które mają pozostać poza reżimem ograniczeń zawartym w u.k.u.r., wprowadził postanowienia zawarte w art. 1a, gdzie z zakresu zastosowania ustawy wyłączono nieruchomości, wchodzące w skład Zasobu Własności Rolnej Skarbu Państwa, nieruchomości rolne o powierzchni mniejszej niż 0,3 ha, stanowiące drogi wewnętrzne oraz w przypadku udziałów we współwłasności dwóch ostatnich kategorii gruntów. Jak widać, walor ogólny mają tylko wyłączenia przedmiotowe. Ponadto argumentacja o ogólnym charakterze wyłączeń dotyczących osób bliskich spod reżimu poszczególnych instrumentów prawnych przewidzianych w u.k.u.r. nie ma uzasadnienia aksjologicznego, które by można wiązać z gospodarką rodzinną w rolnictwie.

Otóż uregulowanie statusu osób bliskich w u.k.u.r. nie jest w jakikolwiek sposób - wbrew stanowisku Sądu Najwyższego - uregulowane tak, aby wzmocnić pozycję gospodarstwa rodzinnego. Przeczy temu sama konstrukcja gospodarstwa rodzinnego w ustawie, jak i brak powiązania statusu osoby bliskiej z gospodarką rodzinną w rolnictwie. Świadczy to o tym, że rozwiązania u.k.u.r., w których przyznaje się preferencje osobom bliskim, mają ,punktowy” charakter; mają znaczenie jedynie w okolicznościach, dla których konkretny przepis przewidział takie konsekwencje.

Na gruncie art. 23 Konstytucji wskazuje się, iż uregulowanie statusu gospodarstwa rodzinnego powinno uwzględniać to, że jeśli chodzi o samo pojęcie „, gospodarstwa rodzinnego", to jest nim gospodarstwo, którego własność pozostaje w zasadzie $w$ rękach jednej rodziny ${ }^{10}$. W piśmiennictwie wskazuje się również, że rodzinnego charakteru gospodarstwa nie przekreśla postugiwanie się praca najemna, pod warunkiem jednoczesnej pracy członków rodziny $w$ tym gospodarstwie $e^{11}$. Za podstawowe kryterium należy uznawać strukturę własności, która powinna pozostawać w rękach jednej, w zasadzie, rodziny. W ujęciu nauk ekonomicznych, gospodarstwo rodzinne cechuje się tym, że jest prowadzone przez członków rodziny i oparte na ich pracy; jest połączone w jeden organizm z gospodarstwem domowym; w przeważającej mierze jest źródłem dochodu rodziny i zachowana jest ciągłość pokoleniowa

10 Tak w uzasadnieniu wyroku Trybunału Konstytucyjnego z dnia 7 maja 2014 r., sygn. K 43/12.

11 L. Garlicki, Komentarz do art. 23 Konstytucji, (w:) L. Garlicki, M. Zubik (red.), Konstytucja Rzeczypospolitej Polskiej. Komentarz. Tom I, Warszawa 2016, Lex - wersja elektroniczna. 
w gospodarstwie (gospodarstwo jest przejmowane w obrębie rodziny przez następ(ę) $)^{12}$.

Łatwo zauważyć, że uregulowanie gospodarstwa rodzinnego w u.k.u.r. nie ma wiele wspólnego ze wskazanymi cechami gospodarstw rodzinnych. W piśmiennictwie zwrócono już uwagę na to, że konstrukcja zastosowana w u.k.u.r. jest atrapą gospodarstwa rodzinnego, rozumianego w sposób zaprezentowany powyżej, z uwagi na brak powiązania z jakimikolwiek cechami determinującymi jego rodzinnośćc ${ }^{3}$.

Abstrahując od „,nierodzinności” gospodarstwa rodzinnego w u.k.u.r., trudno doszukać się w uregulowaniu pozycji osoby bliskiej jakiegoś iunctim z pozycją podmiotu prowadzącego gospodarstwo rodzinne rozumianego w sposób określony w treści ustawy, nie wspominając już o tym, że nie ma nic wspólnego z cechami gospodarstwa rodzinnego w ujęciu postulowanym w piśmiennictwie (na gruncie Konstytucji, jak i nauk ekonomicznych). Innymi słowy, odstępstwa poczynione w treści u.k.u.r. na rzecz osób bliskich nie mają żadnego zakotwiczenia w preambule ustawy ani w jej celach wskazanych w art. 1. Nabycie nieruchomości przez osobę bliską zbywcy jest uniezależnione od późniejszego sposobu wykorzystania tej nieruchomości przez nabywcę, w szczególności od tego, czy będzie ona tworzyła gospodarstwo rodzinne ani czy w ogóle będzie tam prowadzona działalność rolnicza. Nic nie stoi na przeszkodzie, aby właściciel nieruchomości rolnych wchodzących w skład gospodarstwa rodzinnego - powodując likwidację tej jednostki produkcyjnej - wyzbył się własności na rzecz osób bliskich niemających nic wspólnego z rolnictwem, a traktujących nabyte grunty, przykładowo, jako lokatę kapitału albo mających względem nieruchomości plany ich wykorzystania zakładające nierolniczą eksploatację. Ustawa tworzy ramy dla takich zachowań i trzeba uznać, że ustawodawca świadomie dopuszcza taką ewentualność.

W rzeczywistości ustawodawca, wprowadzając preferencje na rzecz osób bliskich w ramach mechanizmów przewidzianych w przepisach u.k.u.r. uznał, że wartości, które realizować mają owe mechanizmy służące kształtowaniu struktury gruntowej polskiego rolnictwa w przypadkach, w których uwzględnione w poszczególnych przepisach zostały preferencje dla osób bliskich, ustępują wartościom, które związane są ze swobodą dysponowania mieniem rolnym w obrębie wąsko zakreślonych członków rodziny. Stąd w rzeczywistości preferencje dla osób bliskich osłabiają skutek oddziaływania regulacji u.k.u.r. zgodnie z deklarowanymi celami ustawy. Rozszerzające traktowanie przewidzianych w poszczególnych przepisach u.k.u.r. wyjątków dotyczących osób bliskich jest więc mocno problematyczne.

12 J. Żmija, M. Szafrańska, Społeczne aspekty funkcjonowania rodzinnych gospodarstw rolnych w Polsce, http:// ksow.pl/analizy-i-ekspertyzy.html (dostęp: 15.10.2017).

13 S. Prutis, Status prawny rodzinnego gospodarstwa rodzinnego w polskim prawie rolnym (ocena stanu regulacji), (w:) Prawne mechanizmy wspierania i ochrony rolnictwa rodzinnego w Polsce i innych państwach Unii Europejskiej, pod red. P. Litwiniuka, Warszawa 2015, s. 11 i nast. 
Powyższa krytyka stanowiska Sądu Najwyższego nie oznacza w żadnym razie aprobaty dla rozwiązań przyjętych w treści u.k.u.r., w szczególności uregulowania art. 2b u.k.u.r. ${ }^{14} \mathrm{~W}$ związku z wykazywanymi w literaturze ułomnościami zawartych tam rozwiązań nie budzi wątpliwości postulat odwoływania się do wykładni celowościowej w toku egzegezy przepisów u.k.u.r. ${ }^{15}$ Trzeba jednak mieć na uwadze, że odstępstwa od wykładni językowej powinny być aplikowane z rozwagą. W przypadku rozstrzygania kwestii możliwości nabycia nieruchomości rolnej przez osobę bliską właściciela, na którym ciążą obowiązki określone w art. 2b ust. 1 i 2 u.k.u.r., nie wydaje się abyśmy mieli - nie dopuszczając takiej możliwości na gruncie reguł wykładni językowej - do czynienia z rezultatami rażąco niesprawiedliwymi, niedającymi się zaakceptować. Natomiast nadmiernie liberalne podejście do kwestii naruszania językowego znaczenia tekstu prawnego ze względów funkcjonalnych, prowadzące do przełamania rezultatów wykładni językowej z relatywnie błahych powodów niesie zagrożenie ,rozlania się” takich tendencji interpretacyjnych również na grunt innych aktów prawnych, co niekoniecznie dobrze przysłuży się bezpieczeństwu obrotu prawnego, gdzie przewidywalność rozstrzygnięć organów stosujących prawo jest wartością samą w sobie. A nie trzeba tłumaczyć, że takiej przewidywalności sprzyja odwołanie się do reguł wykładni językowej.

Należy odpowiedzieć sobie na pytanie, czy - przy negatywnej ocenie rozwiązań zawartych w art. 2b u.k.u.r. - kolejne występujące w praktyce przypadki (a takowe z pewnością się pojawią), w których ewentualnie mniej lub bardziej poważne argumenty funkcjonalne, słusznościowe, wskazywałyby na zasadność poszerzania (wbrew językowemu brzmieniu art. 2b ust. 4 u.k.u.r.) katalogu okoliczności, w których dopuszczalne jest zbycie nieruchomości na rzecz osoby trzeciej - znalazłyby odzwierciedlenie w praktyce stosowania u.k.u.r., co tym samym uczyniłoby z tego przepisu nic nieznaczącą formułę, wydrenowaną z jakiegokolwiek znaczenia.

Wydaje się, że lepiej byłoby w sposób funkcjonalny podejść do sposobu rozumienia przesłanki warunkującej wydanie przez sąd zezwolenia na zbycie nieruchomości albo na oddanie jej w posiadanie (vide art. 2b ust. 3 u.k.u.r.). Chodzi o uzasadniającą dokonanie takich czynności przesłankę ,,przyczyn losowych, niezależnych od nabywcy”. Problem ten wymaga odrębnego opracowania. Tu zasygnalizować należy, że w literaturze można odnotować stanowisko dość liberalne w tym względzie, które może być dobrym punktem wyjścia do dyskusji w tej kwestii ${ }^{16}$.

W dużym stopniu zasadne są zastrzeżenia Rzecznika Praw Obywatelskich w tej mierze zawarte w treści pisma RPO z dnia 4 maja 2017 r., znak IV.7005.8.2017.MC, https://www.rpo.gov.pl/sites/default/files/pismo\%20 procesowe \%20do\%20SN\%20przyst\%C4\%85pienie\%20do\%20post\%C4\%99powania\%20i\%20stanowisko\%20 RPO\%204.05.2017\%20.pdf

15 Por. Z. Truszkiewicz, Nieruchomość rolna i gospodarstwo rolne w rozumieniu U.K.U.R, „Krakowski Przegląd Notarialny” 2016, nr 2, s. 157-158, gzie autor zawarł następującą myśl: Jakość legislacyjna współcześnie tworzonych aktów prawnych jest tak niska, że wykładnia językowa traci obecnie na znaczeniu, a zdecydowanie zyskuje wykładnia celowościowa i systemowa. Tę wskazówkę interpretacyjną należy w pełni od nieść do u.k.u.r. A. Michnik, Obowiązki nabywcy..., op. cit., s. 118. 


\section{ACQUISITION OF AN AGRICULTURAL PROPERTY BY A PERSON CLOSELY RELATED TO THE SELLER. COMMENTS BASED ON THE RESOLUTION \\ OF THE SUPREME COURT OF 22 JUNE 2017, CASE FILE NO. III CZP 24/17}

Keywords: closely related person, agricultural property, Supreme Court, agricultural system

Provisions of the Polish Act on Shaping of the Agricultural System pose a number of doubts as to their interpretation. In its resolution adopted on 22 June 2017, the Supreme Court decided that an owner of an agricultural property, to whom the 10-year trading prohibition applies, as referred to in Art. $2 \mathrm{~b}$ par. 2 of the Act, is allowed to trade it within that period for the benefit of a closely related person. This opinion raises doubts, as it has no legitimate authorisation in the legal provisions. Furthermore, the functional arguments put forward by the Supreme Court do not provide sufficient justification for the above-mentioned conclusion. In the author's opinion, a number of problems emerging from Art. 2b of the Act on Shaping the Agricultural System could be solved through a functional, flexible interpretation of the prerequisite of "material reasons, irrespective of the buyer", which underlies the court's consent to the disposal of the real property by an owner burdened by trading prohibition.

\section{Bibliografia:}

Bieluk J., Ustawa o kształtowaniu ustroju rolnego. Komentarz, Warszawa 2016.

Machnikowski P. , (w:) System prawa prywatnego. Tom III. Prawo rzeczowe, E. Gniewek (red.), Warszawa 2013

Michnik A., Obowiązki nabywcy nieruchomości rolnej wynikające z ustawy z dnia 11 kwietnia 2003 r., „Krakowski Przegląd Notarialny” 2017, z. 1.

Prutis S., Status prawny rodzinnego gospodarstwa rodzinnego w polskim prawie rolnym (ocena stanu regulacji), (w:) Prawne mechanizmy wspierania i ochrony rolnictwa rodzinnego w Polsce i innych państwach Unii Europejskiej, P. Litwiniuk (red.), Warszawa 2015.

Radwański Z., Zieliński M., (w:) System prawa prywatnego. T. 1. Prawo cywilne - część ogólna, M. Safjan (red.), Warszawa 2013.

Garlicki L., Komentarz do art. 23 Konstytucji, (w:) L.Garlicki, M. Zubik (red.), Konstytucja Rzeczypospolitej Polskiej. Komentarz. Tom I, Warszawa 2016, Lex - wersja elektroniczna.

Truszkiewicz Z., Nieruchomość rolna i gospodarstwo rolne w rozumieniu U.K.U.R, „Krakowski Przegląd Notarialny" 2016, nr 2.

Żmija J., Szafrańska M., Społeczne aspekty funkcjonowania rodzinnych gospodarstw rolnych w Polsce, http://ksow.pl/analizy-i-ekspertyzy.html (dostęp: 15.10.2017). 